\title{
Climate-related differences in zooplankton density and growth on the inner shelf of the southeastern Bering Sea
}

\author{
K.O. Coyle *, A.I. Pinchuk \\ Institute of Marine Science, University of Alaska, Fairbanks, AK 99775-7220, USA
}

\begin{abstract}
Zooplankton abundance and biomass were measured during spring and late summer on the inner shelf of the southeastern Bering Sea in years of climate extremes. Samples were taken during late spring and late summer of three years: 1997, a year of moderate spring ice cover and unusually warm, calm summer conditions; 1998, a year of warm, but stormy summer conditions with very little spring ice cover; and 1999, a year of extensive spring ice cover, cold spring conditions and storms during spring and summer. Mean water column temperature was significantly lower during June 1999 than June 1998 and 1997. Copepod abundance and biomass during June were correlated with mean water column temperature and mean temperature below the thermocline. Mean calanoid abundance during June 1999 was 8-52\% of the mean abundance during 1998 and 1997. Significantly lower abundances during June 1999 were observed for Calanus marshallae, Acartia spp., Pseudocalanus spp. and calanoid nauplii. Significant interannual differences in mean water column temperature and calanoid abundance during late summer (late July-early September) were not detected. The Hirst-Lampitt equations were used to estimate the mean daily copepod production during the warm and cold years. The mean production estimate during warm conditions was $13 \mathrm{mg} \mathrm{C} \mathrm{m}^{-2} \mathrm{~d}^{-1}$, with a range of 3-37 $\mathrm{mg} \mathrm{C} \mathrm{m}^{-2} \mathrm{~d}^{-1}$, similar to previous estimates. Production estimates during the cold spring, 1999, were 3-4\% of the production during warm periods. Assuming a 35\% gross growth efficiency, calanoids could consume an average of $37 \mathrm{mg} \mathrm{C} \mathrm{m}^{-2} \mathrm{~d}^{-1}$ during warm periods, but only about $2.6 \mathrm{mg} \mathrm{C} \mathrm{m}^{-2} \mathrm{~d}^{-1}$ during a cold spring. Comparison of the above estimates to concurrent measures of primary production indicate that during warm, calm seasons, calanoids could remove most or all of the available water column primary production, thus indicating that calanoids may have been food limited. During cool conditions, the calanoids could remove only about $3 \%$ of the estimated daily primary production. Lower postbloom primary production rates and higher calanoid grazing rates may result in substantially lower annual carbon flux to benthic communities on the inner shelf during warm calm years relative to cold years with extensive spring ice cover. () 2002 Elsevier Science Ltd. All rights reserved.
\end{abstract}

\section{Contents}

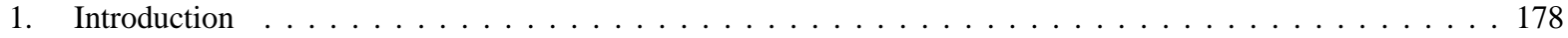

* Corresponding author. Tel.: +1-907-474-7705; fax: +1-907-474-7204.

E-mail address: coyle@ims.uaf.edu (K.O. Coyle). 
2. Methods . . . . . . . . . . . . . . . . . . . . . . . . . . . . . . . 179

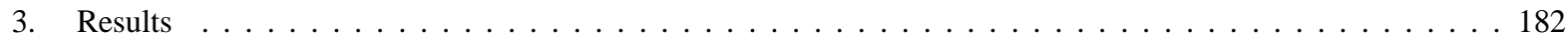

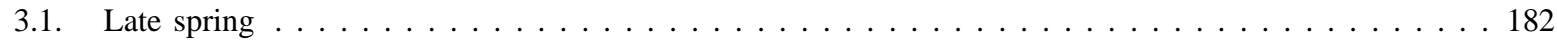

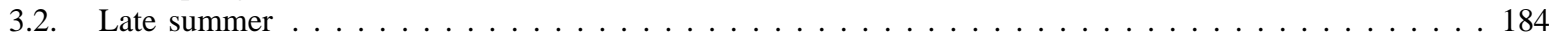

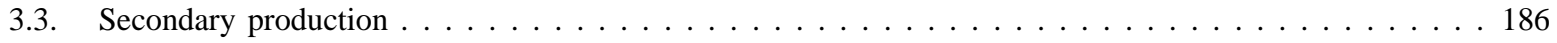

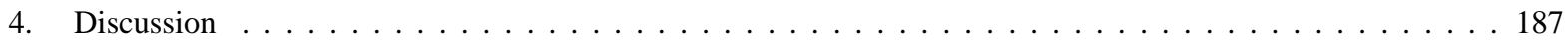

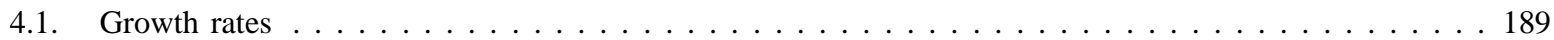

\section{Introduction}

The southeastern Bering Sea shelf sustains valuable wildlife and fisheries resources. In addition to the crustacean, salmon and halibut fisheries, the fishery on pollock (Theragra chalcogramma) alone is worth about 210 million US dollars (Napp \& Hunt, 2001). The region also contains a number of sea bird and marine mammal populations of importance to the indigenous communities and tourist economy. The effects of environmental perturbations on these populations are, therefore, likely to have economic repercussions. Concern for the potential effects of climate variations on resources in the Bering Sea has motivated a number of research efforts aimed at clarifying the links between climate and ecology on the southeastern Bering Sea shelf (Napp \& Hunt, 2001).

Climate perturbations influencing the Bering Sea shelf occur on a number of temporal scales. Effects from the El Niño-Southern Oscillation (ENSO) and the Pacific Decadal Oscillation (PDO) occur at time scales of 3-10 years (Stabeno, Bond, Kachel, Salo, \& Schumacher, 2001). Superimposed over these shortterm oscillations is a long-term warming trend in Alaska as indicated by gradual increases in atmospheric temperature, decreases in the area influenced by permafrost on the land masses near the Bering Sea coast, the retreat of Alaskan glaciers and declines in the thickness and extent of Bering Sea and Arctic Ocean sea ice cover (Chapman \& Walsh, 1993; Osterkamp, 1994; Wadhams, 1995, 2000). As climate models predict that global warming will be most pronounced at higher latitudes (Cattle \& Crossley, 1995), the warming trends are likely to have their greatest impact on Arctic and subarctic ecosystems, including the Bering Sea.

The sensitivity of the Bering Sea ecosystem to climate perturbations has been demonstrated by anomalous conditions related to the recent ENSO events and PDO anomalies in 1997 (Overland, Bond, \& Adams, 2001). The physical oceanographic anomalies involved both unusual water temperatures and alterations in the position and intensity of the frontal systems dividing water masses on the inner shelf (Stabeno et al., 2001). During spring and summer, fronts divide the Bering Sea shelf into three distinct hydrographic regions: the Inner, Outer and Middle domains (Coachman, 1986; Cooney \& Coyle, 1982; Smith \& Vidal, 1986). The Inner domain remains unstratified because the upper and lower water columns are kept mixed well by wind and tide. The Middle domain is a two-layered system, with an upper mixed layer separated from the deeper layer by a seasonal pycnocline at a depth of 20-40 m. The Inner Front that separates the Inner and Middle domains is usually located at the $50 \mathrm{~m}$ isobath (Stabeno et al., 2001). The Outer domain has an oceanic zooplankton species assemblage, consisting of Neocalanus species, Metridia pacifica and Eucalanus bungii. These oceanic copepods are generally absent from the Middle and Inner domains, which contain more neritic species such as Calanus marshallae, Pseudocalanus spp. and Acartia spp. (Cooney \& Coyle, 1982; Smith \& Vidal, 1986). Because cross shelf advection of water masses is generally weak (Coachman, 1986), the zooplankton communities are usually quite distinct (Cooney, 1981; Meshcheryakova, 1964; Motoda \& Minoda, 1974).

Unusually warm and calm weather conditions in spring and summer of 1997 resulted in higher than 
average surface temperatures and the shoreward displacement of the Inner Front from the $50 \mathrm{~m}$ isobath to less than $34 \mathrm{~m}$ depth (Stabeno et al., 2001). In addition, a decrease in the onshore transport of slope water was observed. Along with the unusually calm conditions and warm temperatures, a number of anomalous ecological conditions were observed, including an intense coccolithophorid bloom (Stockwell et al., 2001; Sukhanova \& Flint, 1998), a high mortality of shearwaters (Baduini et al., 2001) and salmon returns far below predicted numbers (Napp \& Hunt, 2001). The unusually warm conditions in 1997 continued into 1998, when the overall heat content of the water column was the highest in recent years (Stabeno et al., 2001). The warm conditions of 1997 and 1998 were followed in 1999 by a cold winter and spring, with extensive penetration of sea ice south into Bristol Bay (Kachel, Salo, Schumacher, Stabeno, \& Whitledge, in press). The years of 1997-1999, therefore, encompassed a period of climate extremes, with both very warm and cold conditions.

During 1997-1999, a multidisciplinary program was completed, which examined the influence of circulation at the Inner Front on various components of the ecosystem from phytoplankton through primary consumers, to apex predators. The zooplankton component focused on determining the species composition, and estimating abundance and biomass of the major mesozooplankton and micronekton populations in the study area. Since mesozooplankton are a critical link between the primary production and higher trophic levels, it was hypothesized that elevated phytoplankton and microzooplankton production at the Inner Front after the spring bloom might promote an increase in mesozooplankton prey populations for fish and marine birds. However, the marked contrast between spring temperatures on the inner shelf of the southeastern Bering Sea during the three-year study provided an opportunity to document the influence of temperature on zooplankton populations and growth rates during late spring and late summer. The following paper describes the differences in zooplankton distribution, abundance, biomass and growth rates as related to temperature during the three-year study. In this paper, the term 'inner shelf' refers to the entire sampling region. The terms 'Inner domain', 'Middle domain' and 'Inner Front' refer to regions having a mixed water column, stratified water column, or the transition zone between the two regions, respectively.

\section{Methods}

Samples were collected on the southeastern Bering Sea inner shelf (Fig. 1) in 1997-1999 on three grids: Port Moller (PM), Cape Newenham (CN) and Nunivak Island (NI) (Table 1). Zooplankton samples and conductivity-temperature-depth (CTD) profiles were taken along a transect through the center of each grid orthogonal to the bathymetry (Fig. 1). CTD profiles were taken with a Seabird model 911 Plus with dual conductivity and temperature sensors. Large zooplankton and micronekton were collected within the sampling grids at 8-12 sites in the Inner domain, Inner Front and Middle domain. The small zooplankton component was sampled with a $25 \mathrm{~cm}$ diameter CalVET system (CalCOFI Vertical Egg Tow; Smith, Flerx, \& Hewitt, 1985) having $150 \mu \mathrm{m}$ mesh nets. Each net was equipped with General Oceanics flowmeters in the mouth of the nets to monitor volume filtered. The net was fished vertically from the bottom to the surface. The large zooplankton component was sampled with a $1 \mathrm{~m}^{2}$ MOCNESS (Wiebe, Burt, Boyd, \& Morton, 1976) with $500 \mu \mathrm{m}$ mesh nets. The MOCNESS was equipped with a flowmeter positioned outside the mouth of the net. Additional sensors included Seabird conductivity and temperature probes. The net was fished at night from about $5 \mathrm{~m}$ above the bottom to the surface. Samples were taken at depth intervals of 5-10 m. The large scyphozoans were removed from the samples, identified, counted and their volume was measured, after which they were discarded. The rest of the material was preserved in a $10 \%$ formalin seawater solution for later analysis.

The zooplankton samples were processed as follows. Each sample was poured into a sorting tray and large organisms, primarily shrimp and jellyfish, were removed and enumerated. The sample was then sequentially split using a Folsom splitter until the smallest subsample contained about 100 specimens of 

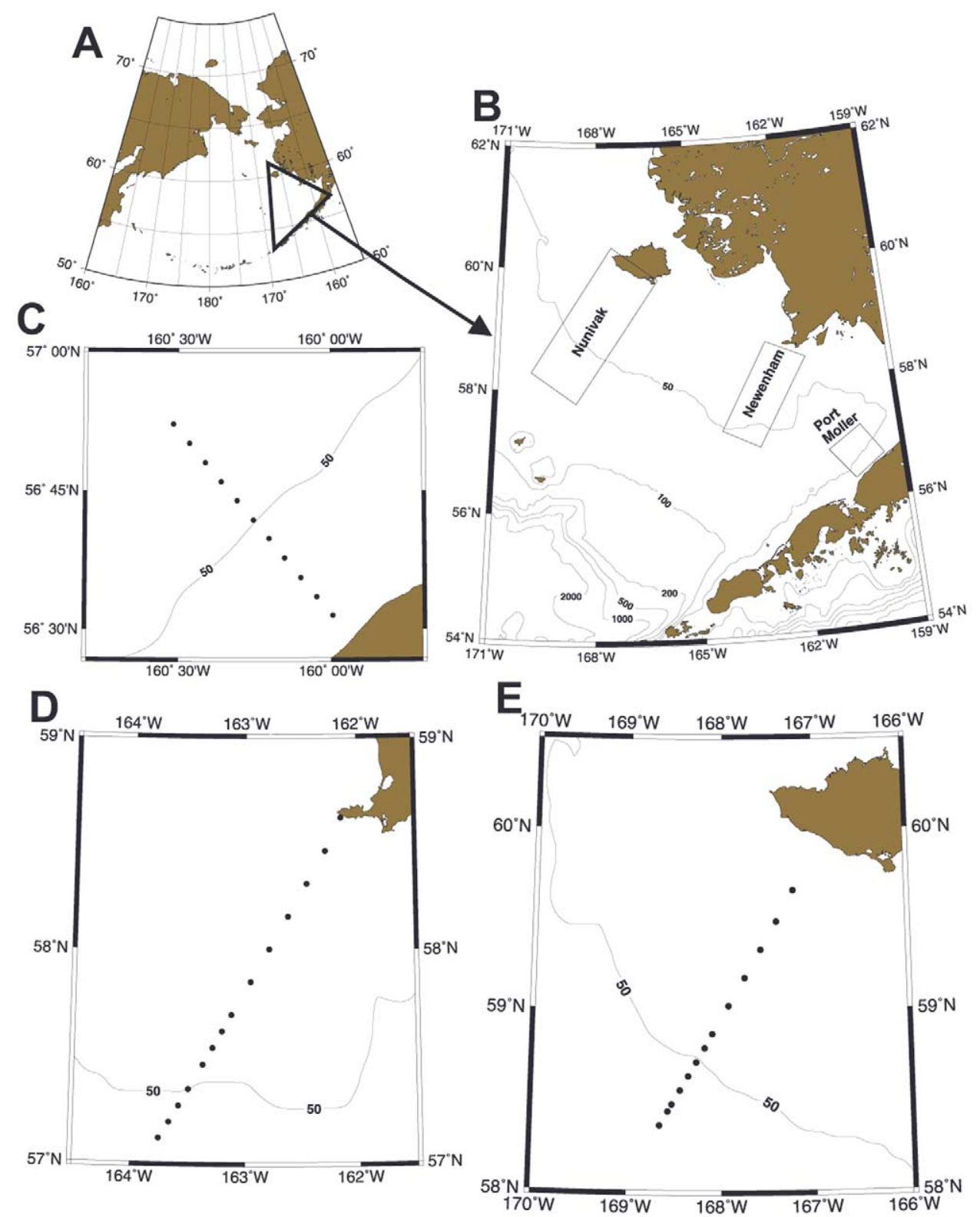

Fig. 1. Location of study region (A,B), PM grid (C), CN grid (D), NI grid (E). Location of CalVET net and CTD stations (solid dots).

the most abundant taxa. The most abundant taxa were identified, staged, enumerated and weighed. Each larger subsample was examined to identify, enumerate and weigh the larger, less abundant taxa. The CalVET samples were subsampled with a Stempel pipette to produce subsamples containing about 100 specimens of the most abundant taxon. Blotted wet weights of all specimens of each taxon and stage were taken on each sample and the coefficient of variation in average wet weight was computed. If the coefficient of variation for any given taxon and stage changed by $<5 \%$ when additional weights were taken from subsequent samples, no further wet weights were measured for that taxon during that cruise. The wet weight 
Table 1

Summary of R/V Alpha Helix cruises at the inner front of the southeastern Bering Sea. Transects sampled for each cruise: PM, CN and NI

\begin{tabular}{llll}
\hline Year & Cruise & Dates & Grids sampled \\
\hline 1997 & HX196 & June 1-27 & PM, CN, NI \\
1997 & HX200 & Aug 30-Sept 11 & NI \\
1998 & HX209 & May 26-June 19 & PM, CN, NI \\
1998 & HX213 & Aug 20-Sept 5 & CN, NI \\
1999 & HX220 & May 20-June 14 & PM, CN, NI \\
1999 & HX222 & July 21-Aug 18 & PM, CN, NI \\
\hline
\end{tabular}

biomass was estimated by multiplying the specimen count by the mean wet weight. In practice, only calanoid copepods had consistent wet weights after weighing each taxon and stage in about 10-15 samples. Therefore, wet weights of euphausiids, shrimp and other larger taxa were measured and recorded individually for each sample. Wet weight measurements were done on a Cahn Electrobalance or Mettler top loading balance, depending on the size of the animal. All animals in the samples were identified to the lowest taxonomic category possible. Copepodid stages were identified and recorded. The data were uploaded to a Microsoft Access database, and analyzed using standard statistics software. The null hypothesis of equal sample means of abundance or biomass was rejected at $P \leq 0.05$.

Only adult and occasionally stage V Acartia were identified to species. Earlier copepodids were identified as Acartia spp. The specimens identified to species were A. longiremis and A. hudsonica. Pseudocalanus were not identified to species, but referred to as Pseudocalanus spp. Species previously reported from the Bering Sea include P. minutus, P. acuspes, P. newmani and P. mimus (Frost, 1989). Statistical analysis on euphausiids was limited to the larval stages in the CalVET tows only. The data for the distributions and abundances of juvenile and adult euphausiids are published elsewhere (Coyle \& Pinchuk, in press).

The depth of the thermocline was computed for each station by locating the depth where $\mathrm{d} T / \mathrm{d} Z$ was maximum $\left(T={ }^{\circ} \mathrm{C}, Z=\right.$ depth, $\left.\mathrm{m}\right)$. The mean water column temperatures above and below the thermocline, and for the total water column were then computed. Analysis of variance was used to look for differences in the mean temperatures above and below the thermocline and for the whole water column by sample grid and year for the spring (June) and late summer (August-September) cruises. The zooplankton data were log-transformed before statistical analysis. Multivariate analysis of variance was also used to identify differences in the abundance of the major taxa by grid and year for the spring and late summer cruises. Canonical correlation was used to compare water column temperatures and abundances of the major taxa at each station. Canonical correlation looks for linear correlations between two sets of random variables, in this case the physical and biological variables. The physical variables consisted of the mean water column temperatures above the thermocline, below the thermocline and for the whole water column, and the pycnocline depth at each station. The biological variables consisted of the abundances of the major taxa at each station. Output consisted of the correlation level, the probability of obtaining correlation if the data were in fact uncorrelated, and the amount of explained variance.

The daily production of calanoid copepods was estimated from daily growth rates computed with a temperature-body size regression (Hirst \& Lampitt, 1998). We used the regressions for broadcast and sac spawners, adult and juveniles:

$$
\log _{10} g=0.0208 T-0.3221 \log _{10}(\mathrm{BW})-1.1408
$$

where $g$ is the growth rate $\left(\mathrm{d}^{-1}\right), T$ is the temperature in ${ }^{\circ} \mathrm{C}$ and $\mathrm{BW}$ is the body weight in $\mathrm{mg} \mathrm{C}$ per individual. Body size in $\mathrm{mg} \mathrm{C}$ was computed from formalin-preserved wet weights for each taxon and stage using the regression equations in Wiebe (1988). The biomass of specimens with individual wet 
Table 2

Mean water column temperature $\left({ }^{\circ} \mathrm{C}\right)$ during June on the southeastern Bering Sea shelf by year (all transects pooled)

\begin{tabular}{|c|c|c|c|c|}
\hline Depth Interval & 1997 & 1998 & 1999 & $P$ \\
\hline MWC & 3.76 & 3.45 & 0.32 & 0 \\
\hline MBT & 3.36 & 3.28 & 0.20 & 0 \\
\hline MAT & 5.53 & 3.79 & 0.45 & 0 \\
\hline
\end{tabular}

MWC, mean water column temperature; MBT, mean temperature below the thermocline; MAT, mean temperature above the thermocline.

weights $\geq 0.3 \mathrm{mg}$ was computed from the MOCNESS samples. Biomass for smaller specimens was computed from the CalVET samples. The biomass for each taxon and stage was integrated for the water column and converted to $\mathrm{mg} \mathrm{C} \mathrm{m}^{-2}$ using the above regression (Wiebe, 1988). Mean water column temperature was used in the growth equation. Water temperature for the MOCNESS samples was taken from the MOCNESS header file for each tow. Temperature for the CalVET samples was taken from the CTD water column profile at each CalVET station.

\section{Results}

\subsection{Late spring}

An analysis of variance indicated that the mean water column temperature above and below the thermocline and the mean temperature for the entire water column were significantly different between years during the spring cruises for all transects pooled (Table 2). Tukey and Bonferroni tests indicated that the mean temperature above the thermocline was cooler in 1998 than in 1997. Both mean temperature below the thermocline and the mean water column temperatures were the same in 1997 and 1998, but were significantly lower in 1999. Thus, the mean temperatures were significantly lower at all depths in 1999 relative to 1998 and 1997. Significant differences were also observed between grids (Table 3). Tukey and Bonferroni tests revealed that temperatures at the NI site were significantly lower than at CN and PM sites during the spring cruises.

Since the NI grid was sampled during all cruises, the distribution of temperature and major taxa along the transect is presented in detail for both spring and late summer for all three years (Figs. 2 and 3). In the spring of 1997 mean temperatures above the thermocline were higher than in the springs of 1998 and 1999, as a result of a well-developed thermocline in the upper $20 \mathrm{~m}$ (Fig. 2). The thermocline extended shoreward to the $30 \mathrm{~m}$ isobath (at $\mathrm{km} \mathrm{80)}$ ), but was not observed inshore of the $50 \mathrm{~m}$ isobath (at about $180 \mathrm{~km}$ ) during the subsequent years. The copepod community was dominated by Pseudocalanus spp. along the entire transect in 1997. Calanoid nauplii were most abundant on the outer half of the transect

Table 3

Mean water column temperature $\left({ }^{\circ} \mathrm{C}\right)$ during spring on the southeastern Bering Sea shelf by transect (all years pooled)

\begin{tabular}{|c|c|c|c|c|}
\hline Depth interval & $\mathrm{PM}$ & NI & $\mathrm{CN}$ & $P$ \\
\hline MWC & 2.80 & 2.01 & 2.70 & 0 \\
\hline MBT & 2.65 & 2.56 & 3.44 & 0 \\
\hline MAT & 3.77 & 1.74 & 2.45 & 0 \\
\hline
\end{tabular}




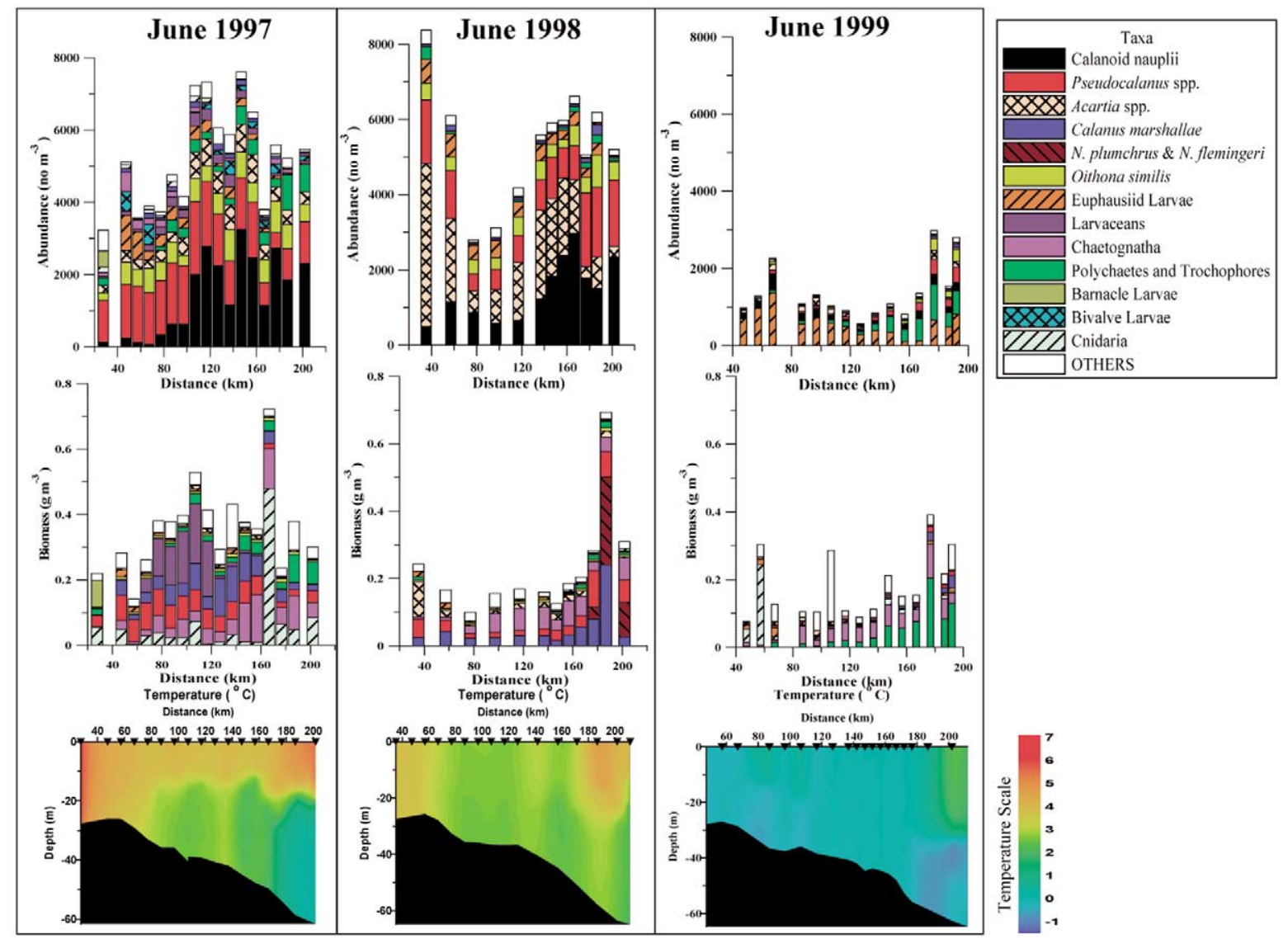

Fig. 2. Abundance and biomass of the major taxa on the NI grid on the inner shelf of the southeastern Bering Sea during spring, 1997-1999, from CalVET data. Temperature sections shown below. Solid triangles indicate station locations.

beyond km 100. Biomass was dominated by chaetognaths (Sagitta elegans), Oikopleura sp., Pseudocalanus spp. and C. marshallae. Oikopleura was not a major contributor to biomass in either 1998 or 1999.

During 1998 abundance was dominated by Acartia spp. along the entire line out to the Inner Front at km 180 (Fig. 2). Calanoid nauplii were again abundant on the outer end of the line and Pseudocalanus was abundant along the entire transect. Biomass at the innermost stations was dominated by Acartia spp. However, biomass on the remainder of the line was dominated by chaetognaths and $C$. marshallae. About half of the biomass at the two outermost stations consisted of Neocalanus plumchrus and N. flemingeri. The spring cruise of 1998 was the only time during the study when Neocalanus species contributed substantially to the biomass on the inner shelf.

In spring 1999, zooplankton abundance on the inner shelf was about two-thirds lower than during the springs of the previous two years (Fig. 2). Euphausiid larvae and meroplankton (polychaetes and trochophores) dominated, and calanoid nauplii were a minor component of the abundance, suggesting that copepod recruitment was lower during June of 1999 than during June of the previous two years. Copepods made up only about half of the abundance. Biomass was dominated by chaetognaths and meroplankton. The high biomass in the 'other' category at km 110 was because of the adult euphausiids in the CalVET tow. Calanoid copepods were a minor constituent of the overall biomass.

A multivariate analysis of variance on abundance of the major zooplankton taxa on all grids for the 


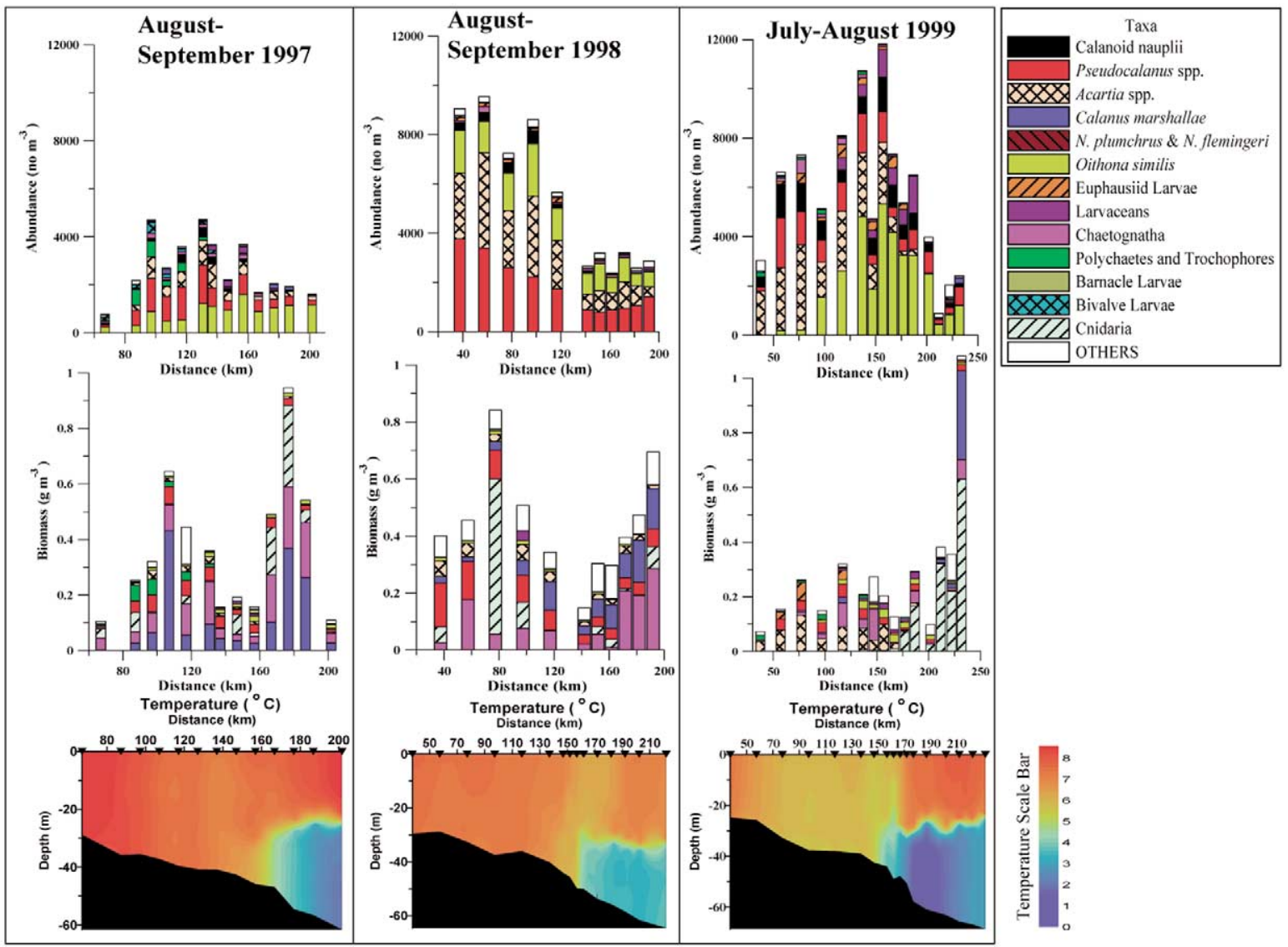

Fig. 3. Abundance and biomass of the major taxa on the NI grid on the inner shelf of the southeastern Bering Sea during late summer, 1997-1999, from CalVET data. Temperature sections shown below. Solid triangles indicate station locations.

spring cruises indicated highly significant differences in abundance between years and sampling grids $(P<0.00001)$. The interaction term was also significant $(P<0.0001)$. Tukey tests revealed that the abundances of $C$. marshallae, Pseudocalanus, Acartia and calanoid nauplii were all significantly lower in 1999 than during the previous two spring cruises (Table 4). In addition to calanoids, the abundance of bivalve larvae was also significantly lower in 1999 than in previous years. The abundances of chaetognaths and other meroplankton did not conform to the above pattern. Tests on the abundance of euphausiid larvae between years did not reveal significant differences.

\subsection{Late summer}

During August and early September the Inner Front was located near the $50 \mathrm{~m}$ isobath in all three years (Fig. 3). Temperatures in the Inner domain were generally $>7{ }^{\circ} \mathrm{C}$ during 1997 and 1998 . A considerably cooler region $\left(<4{ }^{\circ} \mathrm{C}\right)$ persisted on the stratified side of the front during 1999. Analysis of variance did not reveal significant differences in temperature among years on the inner shelf during the late summer cruises (all cruises and transects combined). However, the analysis did indicate that above the thermocline temperatures within the NI grid were consistently lower by $1-2{ }^{\circ} \mathrm{C}$ than within the other two grids. Although the overall zooplankton abundances during the late summer period appeared to be lower in 1997 (Fig. 3), 
Table 4

Tukey test for differences in abundance $\left(\mathrm{No} \mathrm{m}^{-3}\right.$ ) of individual zooplankton taxa (pooled for all sampling grids) on the inner shelf of the southeastern Bering Sea during June. old numbers indicate significant differences at $P \leq 0.05$

\begin{tabular}{|c|c|c|c|c|}
\hline \multirow[t]{2}{*}{ Taxon } & \multicolumn{3}{|c|}{ Mean abundance } & \multirow[t]{2}{*}{ Comments } \\
\hline & 1997 & 1998 & 1999 & \\
\hline Acartia spp. & 961.0 & 711.0 & 64.0 & 99 was lower \\
\hline C. marshallae & 34.0 & 72.0 & 3.7 & 99 was lower \\
\hline Pseudocalanus spp. & 1168.0 & 893.0 & 240.0 & 99 was lower \\
\hline Calanoid nauplii & 616.0 & 626.0 & 322.0 & 99 was lower \\
\hline O. similis & 99.0 & 219.0 & 28.0 & 98 was higher \\
\hline Chaetognaths & 43.0 & 12.0 & 28.0 & 98 was lower \\
\hline Bivalves & 3.5 & 1.5 & 0.5 & 99 was lower \\
\hline Barnacle nauplii & 2.2 & 1.9 & 2.3 & No differences \\
\hline $\begin{array}{l}\text { Polychaetes and } \\
\text { trochophores }\end{array}$ & 101.0 & 117.0 & 300.0 & $\begin{array}{l}98 \text { was not different } \\
\text { from } 97 \text { or } 99\end{array}$ \\
\hline
\end{tabular}

statistical comparisons yielded no clear pattern (Table 5), with some taxa having either higher or lower abundances in 1999 or 1998 than in the other years.

Canonical correlation was used to compare the abundances of the individual copepodid stages for each taxon with mean water column temperatures above the thermocline, below the thermocline and for the whole water column, and pycnocline depth at each station. The data for $C$. marshallae were taken from the MOCNESS samples, whereas the data for the other taxa were taken from the CalVET net samples. Significant correlations were observed for all species, for both spring and late summer (Table 6). Water temperature in the spring was consistently and positively correlated with calanoid abundance for all the major calanoid species (C. marshallae, Pseudocalanus spp., Acartia spp.; Table 6). Furthermore, the correlations were related primarily to mean temperatures for the whole water column and to mean temperatures below the thermocline. Mean temperatures in the upper mixed layer contributed little to the overall correlations. Water temperatures in the spring accounted for $21-45 \%$ of the observed variance in calanoid

Table 5

Mean abundance $\left(\mathrm{No} \mathrm{m}^{-3}\right.$ ) of major zooplankton taxa from CalVET net data taken on the NI grid on the inner shelf of the southeastern Bering Sea during late summer (late July, August, September). Bold numbers indicate significant differences at $P \leq 0.05$

\begin{tabular}{|c|c|c|c|c|}
\hline \multirow[t]{2}{*}{ Taxon } & \multicolumn{3}{|c|}{ Mean abundance } & \multirow[t]{2}{*}{ Comments } \\
\hline & 1997 & 1998 & 1999 & \\
\hline Acartia spp. & 331.0 & 1316.0 & 464.0 & No difference \\
\hline C. marshallae & 32.0 & 41.0 & 5.0 & 1999 lower \\
\hline Pseudocalanus spp. & 570.0 & 1541.0 & 652.0 & 1998 higher \\
\hline Calanoid nauplii & 56.0 & 53.0 & 457.0 & 1999 higher \\
\hline O. similis & 792.0 & 1041.0 & 935.0 & No difference \\
\hline Chaetognaths & 78.0 & 1.0 & 35.0 & 1998 lower \\
\hline Bivalve larvae & 24.0 & 1.3 & 11.0 & 1998 lower \\
\hline Barnacle larvae & 1.6 & 1.3 & 1.1 & No difference \\
\hline $\begin{array}{l}\text { Polychaetes and } \\
\text { trochophores }\end{array}$ & 21.0 & 61.0 & 57.0 & No difference \\
\hline Larvaceans & 6.0 & 20.0 & 52.0 & No difference \\
\hline
\end{tabular}


Table 6

Summary of canonical correlation analyses relating mean temperature above the pycnocline, mean temperature below the pycnocline and mean water column temperature to abundance of major zooplankton taxa on the southeastern Bering Sea shelf during late spring and late summer, 1997-1999

\begin{tabular}{llllll}
\hline Taxon & Period & $\begin{array}{l}\text { Explained variance } \\
(\%)\end{array}$ & $\begin{array}{l}\text { Correlation } \\
\text { relationship }\end{array}$ & Correlation & Probability \\
\hline Acartia & Spring & 45 & Positive & 0.831 & 0.0000 \\
Pseudocalanus & Spring & 29 & Positive & 0.733 & 0.0000 \\
C. marshallae & Spring & 21 & Positive & 0.714 & 0.0000 \\
Oithona & Spring & 7 & Mixed & 0.519 & 0.0000 \\
Euphausiid larvae & Spring & 15 & Mixed & 0.576 & 0.0000 \\
Acartia & Late summer & 32 & Positive & 0.703 & 0.0000 \\
Pseudocalanus & Late summer & 24 & Positive & 0.687 & 0.0000 \\
C. marshallae & Late summer & 23 & Negative & 0.653 & 0.0000 \\
Oithona & Late summer & 9 & Negative & 0.537 & 0.0006 \\
\hline
\end{tabular}

densities (Table 6). Water column temperature accounted for $7 \%$ of the variance in abundance of Oithona similis (a cyclopoid copepod) and 15\% for euphausiid larvae. The abundance of euphausiid eggs and nauplii were negatively correlated to temperature, while the abundance of calyptopis and furcilia were positively correlated to temperature. In all cases, pycnocline depth contributed little to the correlation; including it in the analysis increased the explained variance by only $0-4 \%$, depending on the taxon.

Canonical correlations on the late summer data revealed either weaker or inconsistent relationships between water temperatures and calanoid abundances (Table 6). While the abundances of Pseudocalanus spp. and Acartia spp. were still positively correlated to water column temperature, the amount of explained variance dropped by 5-13\%. The abundance of $C$. marshallae, however, was negatively correlated to temperature, a reflection of its preference for the stratified side of the Inner Front. The abundance of $O$. similis was also negatively correlated to water temperature. Euphausiid larvae were not abundant enough in the late summer samples to permit statistical analysis.

\subsection{Secondary production}

Production estimates on the inner shelf ranged from under 1 to $>37 \mathrm{mg} \mathrm{C} \mathrm{m}^{-2} \mathrm{~d}^{-1}$ (Table 7). The average daily production at CN and PM during the cold spring (June, 1999) was about 3-4\% of the estimates during the warmer period. Production on the NI grid was always less than that at the other grids, except during the cold spring when it was about double that at the other sites, but even so was then about $30 \%$ of the production at Nunivak during the warmer springs. The highest production in late spring (37

Table 7

Calanoid production rates $\left(\mathrm{mg} \mathrm{C} \mathrm{m} \mathrm{m}^{-2} \mathrm{~d}^{-1}\right)$ on the inner shelf of the southeastern Bering Sea as estimated from the temperature-body size regressions of Hirst and Lampitt (1998)

\begin{tabular}{|c|c|c|c|c|c|c|}
\hline \multirow[t]{2}{*}{ Grid } & \multicolumn{3}{|l|}{ Spring } & \multicolumn{3}{|c|}{ Late summer } \\
\hline & 1997 & 1998 & 1999 & 1997 & 1998 & 1999 \\
\hline PM & 8.75 & 37.15 & 0.69 & - & - & 6.18 \\
\hline $\mathrm{CN}$ & 17.55 & 8.85 & 0.57 & - & 4.19 & 35.68 \\
\hline NI & 3.19 & 5.53 & 1.42 & 6.44 & 8.20 & 6.40 \\
\hline
\end{tabular}


mg C m ${ }^{-2} \mathrm{~d}^{-1}$ ) was observed on the PM grid, where the copepod biomass was dominated by C. marshallae (Fig. 4). Highest production in late summer $\left(36 \mathrm{mg} \mathrm{C} \mathrm{m}^{-2} \mathrm{~d}^{-1}\right)$ was observed on the $\mathrm{CN}$ line, where the

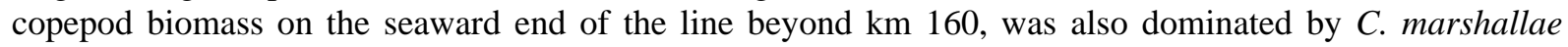
(Fig. 4). The abrupt change in species composition between 150 and $160 \mathrm{~km}$ was at the Inner Front.

\section{Discussion}

The most obvious manifestation of climate variability on the southeastern Bering Sea shelf is the density and extent of annual sea ice cover. The amount of sea ice cover during winter and spring can vary from nil to a dense cover extending south to the Alaska Peninsula and westward to the shelf break (Stabeno et al., 2001). The duration and extent of sea ice is determined by the interaction of the Arctic and Aleutian low pressure systems, which in turn can be influenced by the PDO and ENSO. Generally, strong Aleutian lows are associated with warmer than normal conditions, while weak lows are associated with anticyclones, which pump cold air southward into the Bering Sea (Stabeno et al., 2001). The southward movement of cold air can result in local ice formation and can also blow ice from the northern Bering Sea southward into Bristol Bay. Ice cover conditions in the study area varied from being extensive during the springs of 1997 and 1999 to there being almost no ice during 1998.
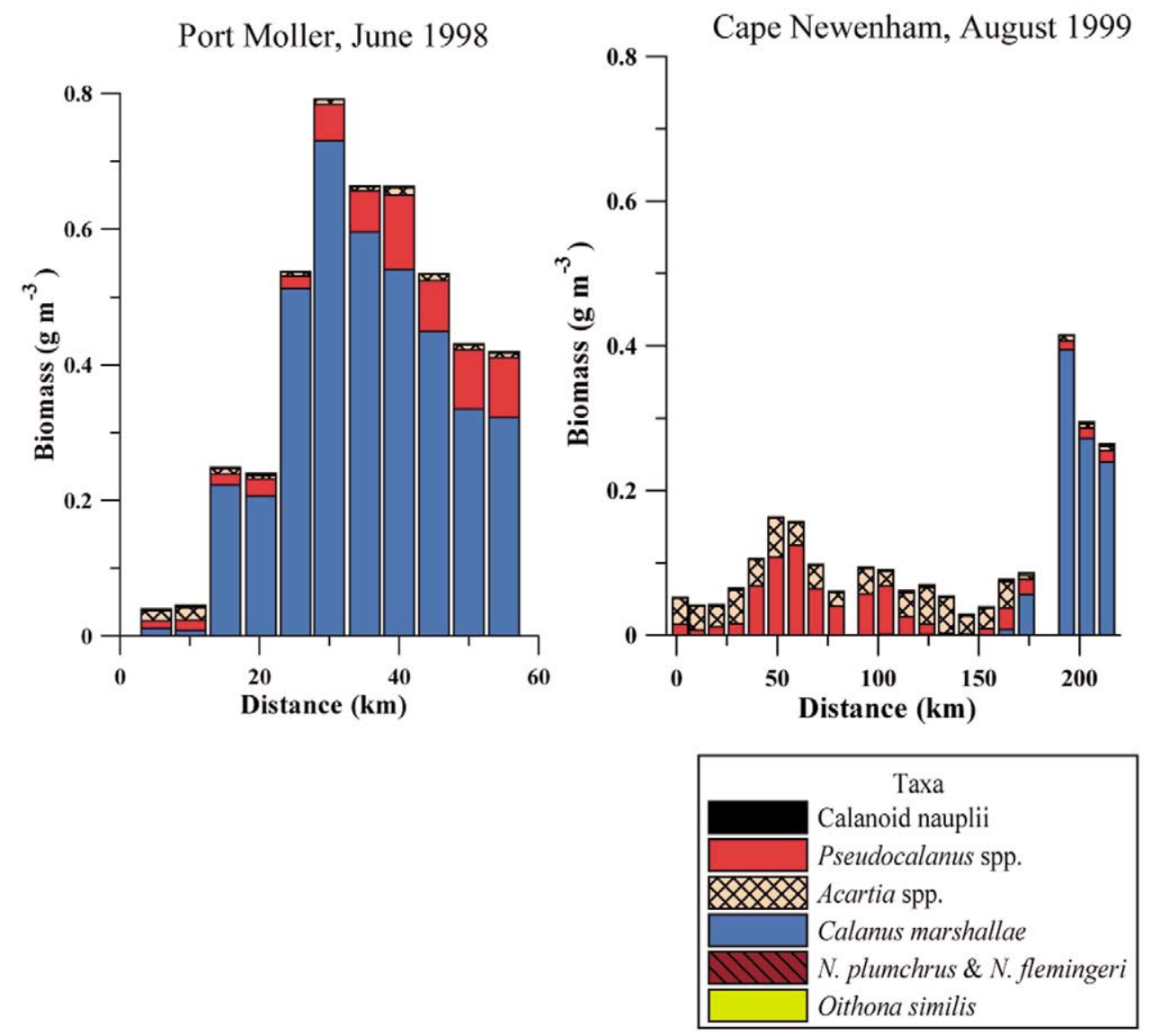

Fig. 4. Copepod biomass in regions of maximum estimated copepod production on the inner shelf of the southeastern Bering Sea. 
Sea ice influences oceanographic conditions by rapidly cooling the water column to depths of up to 80 $\mathrm{m}$ (Stabeno et al., 2001). Water column temperature under the ice can be as low as $-1.7^{\circ} \mathrm{C}$. As conditions warm, the ice retreats leaving a warmer, less-saline water layer over the colder water below the thermocline. The cold water can persist as a 40-50 m thick layer with temperatures $<2{ }^{\circ} \mathrm{C}$ throughout the summer and is referred to as the cold pool (Stabeno et al., 2001). The cold temperatures observed below the thermocline in the 1997 and 1999 CTD transects (Figs. 2 and 3) were a manifestation of the cold pool. The absence of the cold pool from our sampling grids in 1998 was a result of the absence of ice during spring. The consistent observation of cooler mean temperatures on the NI grid relative to the CN and PM grids (Table 3) was because its more northerly location resulted in sea ice occurring there more frequently and with greater persistence.

Intense phytoplankton blooms are observed under the ice (Stabeno, Schumacher, Davis, \& Napp, 1998) and in association with the ice edge during spring (Niebauer, Alexander, \& Henrichs, 1990, 1995). Such blooms may produce up to $65 \%$ of the annual primary production. However, both the ice edge and spring water column bloom are responsible for at least half of the annual production on the outer and middle Bering Sea shelf (Sambrotto, Niebauer, Goering, \& Iverson, 1986). The spring bloom is terminated on the Bering Sea shelf by nutrient depletion in the developing euphotic zone above the thermocline (Whitledge, Reeburgh, \& Walsh, 1986). In most years, the cold pool is a nutrient reservoir, which can fuel post-bloom phytoplankton production (Stockwell et al., 2001). During summer storms can remix nutrients into the upper water column, resulting in periodic summer phytoplankton blooms, which account for up to half of the annual production on the outer and middle shelf (Sambrotto et al., 1986). Thus, primary production estimates of $700 \mathrm{mg} \mathrm{C} \mathrm{m}^{-2} \mathrm{~d}^{-1}$ are common during summer on the middle shelf (Zeeman, 1992) and average rates as high as $2.05 \mathrm{~g} \mathrm{C} \mathrm{m}^{-2} \mathrm{~d}^{-1}$ have been reported from ${ }^{14} \mathrm{C}$ measurements (Walsh \& McRoy, 1986). These observations suggest that during much of the spring and summer in most years, food for calanoids in the Outer and Middle domains up to the Inner Front is probably abundant. Water column primary production in the Inner domain is much lower, with mean rates during a warm, calm year of 113 mg C m${ }^{-2} \mathrm{~d}^{-1}$ (Stockwell et al., 2001). The absence of a nutrient reservoir limits the post-bloom primary production in the Inner domain during summer so that much of the new production is limited to a pulse during the spring bloom (Hansell, Whitledge, \& Goering, 1993). Thus, calanoids in the Inner domain may experience food limitation after the spring bloom has exhausted the available nutrients.

The unusually calm warm conditions in the spring of 1997 generated an intense, shallow thermocline. While nutrients were quickly exhausted above the thermocline, sufficient light penetrated below the thermocline to fuel a deep bloom, which also exhausted the nutrients available in the cold pool below the thermocline (Stockwell et al., 2001). In addition, the unusually calm conditions apparently inhibited crossshelf advection of nutrients from the shelf break (Stabeno et al., 2001). This combination of factors resulted in unusually low nutrient concentrations on the inner shelf and may have been a factor in the development of a coccolithophorid bloom. The late summer phytoplankton community during both 1997 and 1998 contained high concentrations of the coccolithophorid Emiliania huxleyi (Stockwell et al., 2001). Microzooplankton were an important component of the food web during the coccolithophorid bloom (Olson \& Strom, in press). Apparently, most of the primary production in the bloom area was by the larger cell component, the preferred prey of the microzooplankton. A factor in the bloom development was the apparent preference of the microzooplankton for prey other than E. huxleyi (Olson \& Strom, in press).

Feeding experiments suggest that E. huxleyi may not be a preferred prey for Calanus species (Huskin, Anadon, Alavarez-Marques, \& Harris, 2000). A number of studies indicate that some copepod species prefer ciliates or heterotrophic dinoflagellates to plant cells (Nejstgaard, Gizmervik, \& Solberg, 1997; Stoecker \& Capuzzo, 1990). Nevertheless, as much as $75 \%$ of the diet of Calanus finmarchicus can consist of E. huxleyi when the latter is present at sufficiently high concentrations (up to $30 \times 10^{6}$ cells $1^{-1}$, Nejstgaard et al., 1997). Coccolithophorid densities of up to $4.5 \times 10^{6}$ cells $1^{-1}$ were reported for the Bering Sea coccolithophorid bloom (Stockwell et al., 2001). Microzooplankton studies suggest that much of the 
energy consumed by copepods during the coccolithophorid bloom was probably coming from the diatom component through microzooplankton consumers (Olson \& Strom, in press). We observed dense concentrations of $C$. marshallae on the inner shelf during the coccolithophorid bloom. Apparently, production by the coccolithophorid-diatom-microzooplankton assemblage was sufficient to sustain the Calanus populations. Planktivorous whales, including right whales, have been recently observed on the inner shelf off CN (Tynan, DeMaster, \& Peterson, 2001). They may have been attracted to the region by the high concentrations of $C$. marshallae.

In contrast to conditions in 1997 , the spring of 1998 was characterized by much stronger winds and greater cross shelf movement of water masses (Stabeno et al., 2001). The enhanced cross shelf advection apparently swept the oceanic copepod species onto the inner shelf clear into the Inner Front, where they were a dominant taxon in terms of biomass, particularly at the outer two stations of the NI grid. Such large oceanic calanoids can consume a high percentage of the annual primary production (Cooney \& Coyle, 1982; Dagg \& Wyman, 1983), so they may have caused more of the production to move through the pelagic, rather than the benthic food web when they were present on the inner shelf. The oceanic species were not observed on the unstratified side of the developing Inner Front, which apparently inhibited advection of the oceanic copepods further onto the shelf.

Mean water column temperatures in 1999 were lower than 1998 and 1997 as a result of extensive ice cover, which was still present on the NI grid during our sampling period in the latter half of June 1999. The very warm surface layer, which had dominated the inner shelf during 1997 (Fig. 2), was absent in both 1998 and 1999. Nevertheless, the mean water column temperatures during spring of 1997 and 1998 were not significantly different. The unusually warm surface layer in 1997, which covered much of the inner shelf over regions usually occupied by the unstratified conditions of the Inner domain (Stabeno et al., 2001) when averaged with the colder conditions below the thermocline, produced an overall mean water column temperature similar to that observed in 1998. Since calanoid abundance was not significantly different between 1997 and 1998, the calanoid populations were apparently most sensitive to the mean water column temperature rather than the warmer temperature above the thermocline. As a distinct thermocline was absent over most of the sampling grid during spring of 1998 and 1999, the mean water temperature best characterized the thermal regime experienced by the inner shelf zooplankton community.

\subsection{Growth rates}

A variety of models have been suggested for relating zooplankton growth rates, body mass and temperature in copepods (Hirst \& Sheader, 1997; Huntley \& Lopez, 1992; Ikeda \& Motoda, 1975, 1978). Huntley and Lopez (1992) contended that under food-satiated conditions, $90 \%$ of the variation in growth rates could be explained by temperature alone. Others have suggested that while growth and development rates are independent of body mass, fecundity scales with body mass (Kiorboe \& Sabitini, 1995). Comparison of results using a regression on temperature alone, and using a regression on temperature with body mass, revealed that under most conditions, the regression using both independent variables was a better predictor of the measured growth rates (Hirst \& Sheader, 1997). The $R^{2}$ value for the Hirst and Lampitt (1998) regression was 0.435 , indicating that somewhat less than half of the variance was explained by the regression equation. In compiling the data used to generate their regressions, Hirst and Lampitt (1998) used studies in which the copepods were incubated in situ, at ambient temperatures and food concentrations. Data from studies in which food was supplemented were specifically excluded from their regressions. In comparing their results with studies on food-satiated copepods, Hirst and Lampitt (1998) found that in situ growth rates were consistently and significantly below the food-satiated rates. Therefore, food satiation is not an implicit assumption in the application of the Hirst-Lampitt growth equations to natural copepod populations. Note that all studies with zero growth (implying copepods in diapause) were excluded from 
the Hirst-Lampitt data set. Therefore, the Hirst-Lampitt regression will overestimate copepod production in this study if some portion of the populations were in diapause.

Zooplankton production on the middle shelf from March to most of May 1980 was estimated at $40 \mathrm{mg}$ $\mathrm{C} \mathrm{m}^{-2} \mathrm{~d}^{-1}$ or less during a period when temperatures ranged from $0.5^{\circ} \mathrm{C}$ to about $4{ }^{\circ} \mathrm{C}$. The 1980 estimate included production by euphausiids, which comprised $60-85 \%$ of the total (Vidal \& Smith, 1986). Since animals other than copepods contributed $<1 \%$ of the integrated production, production by copepods would have been $6-16 \mathrm{mg} \mathrm{C} \mathrm{m}^{-2} \mathrm{~d}^{-1}$. The above values are similar to those computed by us for the PM and CN grids during the warm spring cruises (June 1997 and 1998; Table 7) when the mean water column temperature was $3.45-3.76{ }^{\circ} \mathrm{C}$ (Table 2). In late May and early June 1980, the zooplankton production reached a maximum of about $150 \mathrm{mg} \mathrm{C} \mathrm{m}^{-2}$ day $^{-1}$ as a result of the increased biomass of late stage copepodids of $C$. marshallae (Vidal \& Smith, 1986). Since the fraction of zooplankton production by euphausiids in 1980 was about $73 \%$ as indicated previously, the copepod production in 1980 would have been about $40 \mathrm{mg} \mathrm{C} \mathrm{m}^{-2}$ day $^{-1}$, which is similar to the highest copepod production estimated for spring and late summer of 1998 and 1999, respectively (Table 7). As in spring of 1980, high copepod production during spring of 1998 was associated with elevated biomass of C. marshallae (Fig. 4).

Because the temperatures in the early 1980s on the southeastern Bering Sea shelf were similar to those during spring of 1997 and 1998 (Stabeno et al., 2001), the per capita production estimates for the two periods should be roughly similar, as our calculations suggest. Note, however, that estimates of calanoid abundance in April/May 1980 and 1981, and June 1981, were considerably below recent values for this study area (Napp et al., in press; Stockwell et al., 2001). CTD data reveal that the mean temperature on the middle shelf during June 1981 was about $5{ }^{\circ} \mathrm{C}$, with no sign of the cold pool associated with spring ice cover (Stabeno et al., 2001). The differences in the estimates of copepod abundance between 1981 and 1997-1998 may be influenced to some degree by differences in gear type between the two studies. Copepod abundances may be underestimated by MOCNESS samples when fine mesh nets are used (see Napp et al., in press, for discussion). Although Napp et al. concluded that the observed differences between the early 1980s and the late 1990s were probably real, comparisons of zooplankton abundance and biomass between studies using different gear types are always complicated by potential biases introduced by the different sampling equipment.

Comparison of production estimates between the early 1980s and late 1990s is also influenced by differences in the method of estimating biomass in terms of carbon. The carbon biomass estimates presented here used the regression of Wiebe (1988) and are about 70\% of those cited in Vidal and Smith (1986) for large animals, and about 80-90\% for small animals. Vidal and Smith (1986) assumed a 45\% conversion factor to convert formalin preserved dry weights to carbon.

Estimated calanoid production during the cold spring of 1999 was only about 3-4\% of production during the warmer years of 1997 and 1998 at CN and PM. The consistently lower production estimates during warmer years at NI relative to $\mathrm{CN}$ and PM may be related to the consistently lower temperatures observed on the Nunivak Grid (Table 3). The much lower correlations between temperature and copepod abundance in late summer relative to spring are an indication that factors other than temperature have a stronger influence on copepod abundance as the season progresses. Additional factors influencing the copepod populations may include food limitation and predation. Elevated predation on small zooplankton is suggested by the higher overall biomass of gelatinous zooplankton observed on the Bering Sea shelf in recent years (Brodeur, Mills, Overland, \& Shumacher, 1999).

The gross growth efficiency $\left(K_{1}=\frac{\Delta W}{\Delta t} \frac{1}{R}\right.$, where $\frac{\Delta W}{\Delta t}=$ growth per unit time and $\mathrm{R}$ is the food consumed, Mauchline, 1998; Parsons, Takahashi, \& Hargrave, 1984) is required to estimate the food consumption from growth. Gross growth efficiency may vary from 1.5 to $89 \%$ (Mauchline, 1998), but most values fall between 10 and $40 \%$ (Parsons et al., 1984). Given the mean calanoid production of $13 \mathrm{mg} \mathrm{C} \mathrm{m}^{-2} \mathrm{~d}^{-1}$, 
and assuming a 35\% gross growth efficiency, during spring of 1997 and 1998, the calanoid population would have been removing $\sim 37 \mathrm{mg} \mathrm{C} \mathrm{m}^{-2} \mathrm{~d}^{-1}$. Given a mean primary production estimate of $113 \mathrm{mg} \mathrm{C}$ $\mathrm{m}^{-2} \mathrm{~d}^{-1}$ for the NI grid during 1997 (Stockwell et al., 2001), the calanoids were removing about 30\% of the daily production. Note however, that nine of the 14 values used to estimate the 1997 mean primary production were $<33 \mathrm{mg} \mathrm{C} \mathrm{m}{ }^{-2} \mathrm{~d}^{-1}$ and four of the values were $<10 \mathrm{mg} \mathrm{C} \mathrm{m}^{-2} \mathrm{~d}^{-1}$. This suggests that most of the calanoids on the inner shelf during the warm, calm spring and summer with intense stratification were probably experiencing food limitation following the initial spring bloom.

Mean primary production during the warm stormy year, 1998, was 526 and $497 \mathrm{mg} \mathrm{C} \mathrm{m}^{-2} \mathrm{~d}^{-1}$ for spring and summer respectively (Zeeman, personal comunication). Values ranged from 18 to $2575 \mathrm{mg} \mathrm{C}$ $\mathrm{m}^{-2} \mathrm{~d}^{-1}$, with only six out of 40 measurements $<35 \mathrm{mg} \mathrm{C} \mathrm{m}^{-2} \mathrm{~d}^{-1}$. During that warm stormy year on an average the calanoids were removing up to about $7 \%$ of the daily production on the inner shelf. During spring of 1999 the estimated calanoid production averaged about $0.9 \mathrm{mg} \mathrm{C} \mathrm{m}^{-2} \mathrm{~d}^{-1}$. Again assuming $35 \%$ growth efficiency, the removal rate by calanoids would have been about $2.6 \mathrm{mg} \mathrm{C} \mathrm{m}^{-2} \mathrm{~d}^{-1}$. Given a mean primary production of $131 \mathrm{mg} \mathrm{C} \mathrm{m}^{-2} \mathrm{~d}^{-1}$ during spring (Zeeman, personal communication), the calanoids were removing, on an average, $<2 \%$ of the mean post-bloom primary production. Earlier measurements of the carbon ingestion rates by the whole zooplankton community during an ice edge bloom on the southeastern Bering Sea shelf indicated that they could remove only about $6.5-32.8 \mathrm{mg} \mathrm{C} \mathrm{m}^{-2} \mathrm{~d}^{-1}$, again $<2 \%$ of the estimated daily production (Coyle \& Cooney, 1988). During the late summer of 1999, mean primary production on the inner shelf was $1414 \mathrm{mg} \mathrm{C} \mathrm{m}^{-2} \mathrm{~d}^{-1}$ (Zeeman, personal communication). Assuming an average calanoid grazing rate of $37 \mathrm{mg} \mathrm{C} \mathrm{m}^{-2} \mathrm{~d}^{-1}$, the calanoids were removing about $2.6 \%$ of the daily primary production, either by consuming the phytoplankton directly or through the microzooplankton food web.

The above observations indicate that changes in climate, which influence the intensity and frequency of storms and the duration and extent of ice cover on the inner shelf of the southeastern Bering Sea, will influence the magnitude and fate of post-bloom primary production. Stormy conditions promote the cross shelf advection of nutrient-rich shelf-break water from the nutrient reservoir of the Bering Sea basin (Stabeno et al., 2001). Storm-generated turbulence erodes the pycnocline, promoting vertical mixing of the nutrient-rich subpycnocline water up into the euphotic zone and enhancing primary production. In addition, cold conditions inhibit zooplankton production, and so permit much of the annual primary production on the inner shelf to sink to the benthic community. The Inner Front primary production measurements indicate that during stormy years, substantial amounts of the estimated annual primary production on the inner shelf occurs after the spring bloom, perhaps up to 50\% (Sambrotto et al., 1986). In contrast, calm warm conditions can inhibit the cross shelf flux of nutrient-rich basin water (Stabeno et al., 2001) and spring-early summer primary production can exhaust the available nitrate nitrogen below the pycnocline (Stockwell et al., 2001). The remaining primary production is generated by recycled nitrogen and our zooplankton production estimates suggest that during a warm and calm year all of the regenerated primary production could be taken by the zooplankton community. These observations suggest that warm and calm conditions may result in a substantial reduction of the annual carbon flux to the benthic community, and this reduction in carbon flux will probably impact the commercial groundfish and crustacean fisheries sustained by production by the benthic community.

A new hypothesis explaining ecological processes on the southeastern Bering Sea shelf has been proposed, the Oscillating Control Hypothesis (OCH; Hunt et al., in press). The OCH states that during cold years when ice blooms predominate, zooplankton production will be low and recruitment of forage fish will be limited by bottom-up processes. During warm periods, the spring bloom will occur later in the year, zooplankton production will be higher and zooplankton populations will be limited by other processes. Under such conditions, forage fish populations will eventually be controlled by predation from larger fish and mammals, a top-down process. Under normal conditions, both bottom-up and top-down processes are hypothesized to occur simultaneously, but in different proportions depending on the temperature. The 
results outlined here appear to support the $\mathrm{OCH}$, in that zooplankton production during the cold spring (1999) was apparently limited by temperature, whereas during the warm springs of 1997 and 1998, and during late summer of all years, zooplankton production was probably controlled by other processes such as predation or food limitation.

\section{Acknowledgments}

This research was conducted on the R/V Alpha Helix. Technical support was provided by the captain, crew and ship's technicians (Steve Hartz and Brian Rowe). Aid in processing zooplankton samples and data entry were provided by Chris Stark, Janet Ballek and Elizabeth Stockmar. This research was a multidisciplinary effort involving the cooperation of researchers from several institutions. They include Phyllis Stabeno, Sigrid Salo, Jim Schumacher and Nancy Kachel from Pacific Marine Environmental Lab; George Hunt, Lucy Vlietstra and Cheryl Baduini from University of California Irvine; Jim Lovvorn from University of Wyoming; Terry Whitledge and Dean Stockwell from University of Alaska Fairbanks; and Steve Zeeman from University of New England. We thank all of the above for their participation in this research effort. This research was funded by Office of Polar Programs, National Science Foundation Grant No. OPP9617287 and OPP-9819273. Supplemental funds for completion of data analysis and manuscript preparation were provided by CIFAR grant number NA67RJ0147.

\section{References}

Baduini, C. L., Hyrenbach, K. D., Coyle, K. O., Pinchuk, A. I., Mendenhall, V., \& Hunt, G. L. Jr. (2001). Mass mortality of shorttailed shearwaters in the south-eastern Bering Sea during summer 1997. Fisheries Oceanography, 10, 117-130.

Brodeur, R. D., Mills, C. E., Overland, J. E., \& Shumacher, J. D. (1999). Evidence for a substantial increase in gelatinous zooplankton in the Bering Sea, with possible links to climate change. Fisheries Oceanography, 8, 296-306.

Cattle, H., \& Crossley, J. (1995). Modeling Arctic climate change. Philosophical Transactions of the Royal Society, London, A352, 201-213.

Chapman, W. L., \& Walsh, J. E. (1993). Recent variation of sea ice and air temperatures in high latitudes. Bulletin of the American Meteorological Society, 74, 33-47.

Coachman, L. K. (1986). Circulation, water masses, and fluxes on the southeastern Bering Sea shelf. Continental Shelf Research, 5, 23-108.

Cooney, R. T. (1981). Bering Sea zooplankton and micronekton communities with emphasis on annual production. In The eastern Bering Sea oceanography and resources (pp. 947-974). Seattle: Office of Marine Pollution Assessment, NOAA University of Washington Press.

Cooney, R. T., \& Coyle, K. O. (1982). Trophic implications of cross-shelf copepod distributions in the southeastern Bering Sea. Marine Biology, 70, 187-196.

Coyle, K. O., \& Cooney, R. T. (1988). Estimating carbon flux to pelagic grazers in the ice-edge zone of the eastern Bering Sea. Marine Biology, 98, 299-306.

Coyle, K. O., \& Pinchuk, A. I. The abundance and distribution of euphausiids and zero-age pollock on the inner shelf of the southeast Bering Sea near the Inner Front in 1997-1999. Deep Sea Research II, 49, PII: S0967-0645(02)00331-4.

Dagg, M. J., \& Wyman, K. D. (1983). Natural ingestion rates of the copepods Neocalanus plumchrus and N. cristatus calculated from gut contents. Marine Ecology Progress Series, 13, 37-46.

Frost, B. W. (1989). A taxonomy of the marine calanoid copepod genus Pseudocalanus. Canadian Journal of Zoology, 67, 525-551.

Hansell, D. A., Whitledge, T. E., \& Goering, J. J. (1993). Patterns of nitrate utilization and new production over the Bering-Chukchi shelf. Continental Shelf Research, 13, 601-627.

Hirst, A. G., \& Lampitt, R. S. (1998). Towards a global model of in situ weight-specific growth in marine planktonic copepods. Marine Biology, 132, 247-257.

Hirst, A. G., \& Sheader, M. (1997). Are in situ weight-specific growth rates body size independent in marine planktonic copepods? A re-analysis of the global syntheses and a new empirical model. Marine Ecology Progress Series, 154, 155-165.

Hunt, G. L. Jr., Stabeno, P., Walters, G., Sinclair, E., Brodeur, R. D., Napp, J. M., \& Bond, N. A. The eastern Bering Sea: evidence for change and a new hypothesis linking ecosystem control and climate. Deep Sea Research II, in press. 
Huntley, M. E., \& Lopez, D. G. (1992). Temperature-dependent production of marine copepods: a global synthesis. American Naturalist, 140, 201-242.

Huskin, I., Anadon, R., Alavarez-Marques, F., \& Harris, R. P. (2000). Ingestion, faecal pellet and egg production rates of Calanus helgolandicus feeding coccolithophorid versus non- coccolithophorid diets. Journal of Experimental Marine Biology and Ecology, 248, 239-254.

Ikeda, T., \& Motoda, S. (1975). An approach to the estimation of zooplankton production in the Kuroshio and adjacent regions. In B. Morton (Ed.), Special symposium on marine sciences (pp. 24-28). Hong Kong: Pacific Science Association.

Ikeda, T., \& Motoda, S. (1978). Estimated zooplankton production and their ammonia excretion in the Kuroshio and adjacent seas. Fisheries Bulletin, 76, 357-367.

Kachel, N. B., Salo, S. A., Schumacher, J. D., Stabeno, P. J., \& Whitledge, T. E. Characteristics of the Inner Front of the southeastern Bering Sea. Deep Sea Research II, 49, PII: S0967-0645(02)00324-7.

Kiorboe, T., \& Sabitini, M. (1995). Scaling of fecundity, growth and development in marine planktonic copepods. Marine Ecology Progress Series, 120, 285-298.

Mauchline, J. (1998). The biology of calanoid copepods. Advances in Marine Biology, 33, 701.

Meshcheryakova, N. M. (1964). Quantitative plankton distribution in the southeast Bering Sea during summer, 1958 and 1959. Trudy Vsesoyuznyy Nauchno-Issledovatel'skiy Institut Morskogo Rybnogo Khozyaystva i Okeanografii (VNIRO) 49, Izvestiya Tikhookeanskiy Nauchno-Issledovatel'skiy Institut Rybnogo Khozyaystva i Okeanografii (TINRO) 51, 141-151 (in Russian).

Motoda, S., \& Minoda, T. (1974). Plankton of the Bering Sea. In D. W. Hood, \& E. J. Kelley (Eds.), Oceanography of the Bering Sea with emphasis on renewable resources (pp. 207-241). Fairbanks, AK: Institute of Marine Science, University of Alaska.

Napp, J. M., Baier, C. T., Brodeur, R. D., Coyle, K. O., Shiga, N., \& Mier, K. Interannual and decadal variability in zooplankton communities of the southeast Bering Sea shelf. Deep Sea Research II, 49, PII: S0967-0645(02)00330-2.

Napp, J. M., \& Hunt, G. L. Jr. (2001). Anomalous conditions in the south-eastern Bering Sea 1997: linkages among climate, weather, ocean and biology. Fisheries Oceanography, 10, 61-68.

Nejstgaard, J. C., Gizmervik, I., \& Solberg, P. T. (1997). Feeding and reproduction by Calanus finmarchicus, and microzooplankton grazing during mesocosm blooms of diatoms and the coccolithophore Emiliania huxleyi. Marine Ecology Progress Series, 147, 197-217.

Niebauer, H. J., Alexander, V. A., \& Henrichs, S. M. (1990). Physical and biological oceanographic interactions in the spring bloom at the Bering Sea marginal ice zone. Journal of Geophysical Research, 95, 22229-22242.

Niebauer, H. J., Alexander, V. A., \& Henrichs, S. M. (1995). A time-series study of the spring bloom at the Bering Sea ice edge. I. Physical processes, chlorophyll, and nutrient chemistry. Continental Shelf Research, 15, 1859-1877.

Olson, M. B., \& Strom, S. L. Phytoplankton growth, microzooplankton herbivory and community structure in the southeast Bering Sea: insight into the formation and temporal persistence of an Emiliania huxleyi bloom. Deep Sea Research II, 49, PII: S09670645(02)00329-6.

Osterkamp, T. E. (1994). Evidence for warming and thawing of discontinuous permafrost in Alaska. EOS, Transactions, American Geophysical Union, 75, 85.

Overland, J. E., Bond, N. A., \& Adams, J. M. (2001). North Pacific atmospheric and SST anomalies in 1997: links to ENSO. Fisheries Oceanography, 10, 69-80.

Parsons, T. R., Takahashi, M., \& Hargrave, B. (1984). In Biological oceanographic processes (p. 330). Oxford: Pergamon Press.

Sambrotto, R. N., Niebauer, H. J., Goering, J. J., \& Iverson, R. L. (1986). Relationships among vertical mixing, nitrate uptake, and phytoplankton growth during the spring bloom in the southeast Bering Sea middle shelf. Continental Shelf Research, 5, $161-198$.

Smith, P. E., Flerx, W., \& Hewitt R. P. (1985). The CalCOFI vertical egg tow (CalVET) net. In Lasker, R., (Eds.), An egg production method for estimating spawning biomass of pelagic fish: application to the northern anchovy Engraulis mordox. 23-33, NOAA Technical Report, Washington, D.C.: NMFS 36, US Department of Commerce.

Smith, S. L., \& Vidal, J. (1986). Variations in the distribution, abundance, and development of copepods in the southeastern Bering Sea in 1980 and 1981. Continental Shelf Research, 5, 215-239.

Stabeno, P. J., Bond, N. A., Kachel, N. B., Salo, S. A., \& Schumacher, J. D. (2001). On the temporal variability of the physical environment over the south-eastern Bering Sea. Fisheries Oceanography, 10, 81-98.

Stabeno, P. J., Schumacher, J. D., Davis, R. F., \& Napp, J. M. (1998). Under-ice observations of water column temperature, salinity, and spring phytoplankton dynamics: eastern Bering Sea shelf. Journal of Marine Research, 56, 239-255.

Stockwell, D. A., Whitledge, T. E., Zeeman, S. I., Coyle, K. O., Napp, J. M., Brodeur, R. D., Pinchuk, A. I., \& Hunt, G. L. Jr. (2001). Anomalous conditions in the south-eastern Bering Sea, 1997: nutrients, phytoplankton and zooplankton. Fisheries Oceanography, 10, 99-116.

Stoecker, D. K., \& Capuzzo, J. M. (1990). Predation on protozoa: its importance to zooplankton. Journal of Plankton Research, 12, 891-908.

Sukhanova, I. N., \& Flint, M. V. (1998). Anomalous blooming of coccolithophorids over the eastern Bering Sea. Okeanologiya, 38, 502-505. 
Tynan, T. C., DeMaster, D. P., \& Peterson, W. T. (2001). Endangered right whales on the southeastern Bering Sea shelf. Science, 294,1894

Vidal, J., \& Smith, S. L. (1986). Biomass, growth, and development of populations of herbivorous zooplankton in the southeastern Bering Sea during spring. Deep-Sea Research, 33, 523-556.

Wadhams, P. (1995). Arctic sea ice extent and thickness. Philosophical Transactions of the Royal Society, London, A352, $301-319$.

Wadhams, P. (2000). Further evidence of ice thinning in the Arctic Ocean. Geophysical Research Letters, 27, 3973-3975.

Walsh, J. J., \& McRoy, C. P. (1986). Ecosystem analysis in the southeastern Bering Sea. Continental Shelf Research, 5, $259-288$.

Whitledge, T. E., Reeburgh, W. S., \& Walsh, J. J. (1986). Seasonal inorganic nitrogen distribution and dynamics in the southeastern Bering Sea. Continental Shelf Research, 5, 109-132.

Wiebe, P. H. (1988). Functional regression equations for zooplankton displacement volume, wet weight, dry weight, and carbon: a correction. Fishery Bulletin, 86, 833-835.

Wiebe, P. H., Burt, K. H., Boyd, S. H., \& Morton, A. W. (1976). A multiple opening/closing net and environmental sensing system for sampling zooplankton. Journal of Marine Research, 34, 313-325.

Zeeman, S. I. (1992). The importance of primary production and $\mathrm{CO}_{2}$. In P. A. Nagel (Ed.), Results of the Third Joint US-USSR Bering and Chukchi Seas Expedition (BERPAC), summer 1989 (pp. 218-224). Washington, DC: US Fish and Wildlife Service. 